\title{
Modification of Social Identity in Experience-Toughened Trans-Migrant Agricultural Workers
}

\author{
Keith V. Bletzer* \\ School of Human Evolution and Social Change, Arizona State University, USA
}

\begin{abstract}
Diversion and subversion occur in the playful humor in which trans-migrant farm workers engage to alleviate the gruffness and roughness of farm labor and to re-assert the human potential for creativity, with words, if not in action and behavior. This essay considers nuances of the humor response in formal interviews as markers of significant points of transition. Narrators use humor to reflect on alterations in behavioral experience that directly affect the personal identity they have come to accept and to believe is a reasonable representation of who they are.
\end{abstract}

Keywords: Trans-migrants and immigrants, farm work, humor, resilience, identity.

Told that we are "post" the second of two social revolutions that mark us as different from the eras that preceded each, we bear witness through the ethnographic enterprise to a potential within the Information Era for minimization of the human capacity for creativity [1-2] and dissuasion against any resistance to social domination [3]. These possibilities affect those spaces and settings where people converge to perform activities related to what, for some represents industrial work (the second social revolution), and what, for some represents agricultural work (the first social revolution). One learns by spending time in these spaces and settings: this is the foundation of ethnographic enterprise. For more than a decade, I co-occupied spaces with men and women who perform or have performed farm labor, particularly in low-income, high-risk areas where they spent time when not working. I encountered the sense of play as resistance described by José Limón [2, 4] among men and women whom he studied in south Texas, and by Ron Jenkins [5], who reviewed historic and contemporary examples of ways that play and humor generate a forum to seek potential solutions to social injustice and institutional oppression.

Little studied among agricultural workers, the narrative quality of play and humor has long been a part of the farm labor experience. One of the early advocates for improving the living and working conditions of farm workers was the American novelist, John Steinbeck. At one point, he wrote on the lighter side of farm labor, poetically linking humor (jokes in particular) to the relief that it provided from the everyday troubles and worries of economic survival that was the core of the farm labor experience.

The migrant people, scuttling for work, scrabbling to live, looked always for pleasure... Sometimes amusement lay in speech, and they climbed up their lives with jokes. And it came about in the camps along the roads, on the ditch banks besides the streams, under the sycamores (page 338)... [6].

*Address correspondence to this author at the School of Human Evolution and Social Change, Arizona State University, Tempe, Arizona 85217, USA; E-mail: keith.bletzer@asu.edu
Later in the classic study conducted by William Friedland and Dorothy Nelkin [7] in the late 1960s, the playful humor that was a part of migrant life was described in a section entitled, "The Social Functions of Humor" (pages 155-159). Based on generous notes and the assistance of several graduate students who traveled with migrant crews from the southern United States into farming areas of the northern state of New York, the authors reveal how humor served both as an outlet against a build-up of daily tensions, as well as a means of individual identity maintenance based on storytelling skills and joke construction. Recently, Travis Du Bry [8] and Peter Benson [9] each articulated aspects of the everyday world of farm laborers, although neither of these two field researchers placed emphasis or directed their discussion to the play of humor within daily interactions among farm workers. Finally, an alternative approach to humor in agricultural sites is writing in the genre of everyday narrative replete with humorous episodes, such as the Spanish language novel by Tomás Rivera [10], who presents a tale of migrant life in the western United States in mythic time and space.

In this article, I take a different approach to the study of play and humor in the context of ethnographic investigation. My intent is to explore use of the "humor response" in narratives that mark points of transitions that take place in migrant life rather than consider play and humor from a performative perspective [11]. My analysis has benefited from discussions of reflexive acknowledgment of embodied agency [12], general theories on humor [13, 14], conversational uses of humor $[15,16]$ and Arthur Asa Berger's [17] analysis on humor as verbal and non-verbal expression that adheres to a system of logic. Central to my analysis is an observation by Bruun and Langlais [12] that actors may reflexively recognize actions when they are happening as well as the resultant consequences, and Berger's [17] elaboration of an existential capacity of humor to reveal nuances of social identity across both verbal and non-verbal communication. When it is embedded in narrative talk, the humor response positions a speaker's awareness of what has taken place with enactment of a particular behavior ("embodied agency"). Reviewing a series of life stories collected among agricultural workers, I 
examine instances that a narrator "marks" a story as humorous by behavior that corresponds to laughing, chuckling or giggling. I am less concerned with variations of the "humor response" than I am to its general presence within the narrative and its use in relation to identity formation and maintenance. I am concerned with the link between the situation as it is described by the narrator and the sense of identity culminating from multi-cultural experiences across one, and often two or more, international borders.

\section{METHODOLOGY}

\section{Data Collection}

For more than ten years, I worked with farm workers in relation to social adversity in farm areas of the regions known as the Midwest and the South of the United States. I recently finished a long-term ethnographic study of onset into drug and alcohol use among men and women who perform and/or performed farm work in the eastern United States. These data I use for analysis. Although the main data source was transcribed interviews, I incorporated field encounters into my research plan, wherein I spent time with many of the people whom I formally interviewed. A number of men and women in one farm community in the rural southern United States, for example, I had known for several years through my work with another project. Several others, whom we missed in that study, I recruited for the present study. Everyone whom I formally interviewed, I came to know in farming areas along the East Coast of the United States. Data collection sites were scattered across several states. The six sites where I taped interviews were located in three states: street setting in a small city devoted to agriculture, treatment program for farm workers, as well as a house used by men in remission (not in treatment, having recently completed the drug abuse program), and corrections facilities operated within local jurisdictions (county jail and town stockade). All together, I spent time in three primary data collection sites and eleven casual data collection sites that were distributed across five southern states.

I used "ethnographic sampling" [18] to select individuals in the field to represent extreme as well as typical cases based on experience in farm work (childhood to adulthood, childhood or adulthood only), non-agricultural experience (city, rural, both; outside and within the United States), drug use by duration (long-term, intermediate, short-term) and by type (hard drugs or alcohol) and lifetime travel-work (transnational from one country to another, across regions in the USA, or local in one state only). I completed more than 200 formal interviews with 160 unduplicated persons. Onehundred-and-forty were persons who were using currently or had used drugs in the recent past (20 of the 160 had not used drugs); considering involvement in agriculture, 103 were currently active in farm labor, and 41 were inactive and 16 had never performed farm work. All together I interviewed 60 transnational individuals among the total sample of 160; two-thirds were born in Mexico, and the rest were born in Central America or the Caribbean. Material for this paper comprises a random selection of ten interviews with these transnational men and women. I chose these individuals given their more varied experience across national borders. Since all of the interviews including those with transnational workers had instances of the humor response, I selected a set of ten interviews for analysis.

\section{Transcription}

Interviews were transcribed with notations for linguistic and narrative nuances as well as their imbedded content. To avoid subjective selection of excerpts of humor, I randomized the full set for reviewing transcripts to document my thesis that farm workers use the humor response to mark events and incidents in their life that affected a later view of their place in the world around them. I analyze instances where "humor response" occurred (chuckle, laugh, giggle) to ascertain the most common and salient aspects of the context that was being elaborated in narrative talk.

\section{The Sample}

Given the frequent appearance of humorous anecdotes and the humor response, it was not necessary to search deeply into the overall sample to find cases for narrative analysis. Four of the ten cases were duplicates; seven men and one woman generated the ten transnational interviews. National origins and gender for these eight persons are similar to their proportions in farm labor across the United States. Four men and the one woman were born in Mexico, two men were born in El Salvador, and one man was raised in the Caribbean (born in New York City, he returned as an infant to his home country). Two of the men were raised in provincial capitals (Mexico), and the remaining six had spent childhood and most of their youth in rural areas. Two men from El Salvador were raised in separate, rural provinces. The woman and one man were born and raised in the same province in Mexico (she in a rural area; he in the capital city). All eight persons had lived and worked in the United States for five or more years, and each had worked in other states for more than a year than one where they were formally interviewed. Four had spent more than 12 years in the United States, mostly in agricultural areas from the southern United States.

The age of the eight selected individuals was slightly older than the growing trend of younger transnational men and women who currently are encountered performing farm work [19-21]. The sample of eight persons, then, leans more toward experienced persons than young people who currently trans-migrate (another term that reflects the mobility of persons working in farm labor). Mean age of the eight persons was 33.8 years. Six of the eight were in their 30 s at the time they were interviewed; the woman (Mexico) was in her 20s, and one man (El Salvador) was in his 40s. Their experience of entering this country was typical of men and women who immigrate to the United States with little money [22-24]. Two persons from Central America crossed the border once on their own, before they later crossed on return trips with others who were friends or kin, rather than the coyotes that facilitate "border-crossing" both from Mexico into the United States and return from the United States into Mexico [25, 26]. The other four first crossed the border assisted by coyotes; two later crossed with kin and/or friends. Two of six from Central America crossed twice (went home once, but he returned); one crossed four times; one crossed five times (the only one who was caught; he stayed briefly in Mexico before eventually returning); and the woman and the oldest man crossed but once. Neither of these latter two, or the man who was raised in the Caribbean, had returned home since coming to the states. None of the men or woman from 
Mexico had documents ("papers") when they first came to the United States. The man from the Caribbean was a U.S. citizen by birth, despite being raised outside the states in his mother's home country.

Considering drug and alcohol use, the men in the sample were less typical than men who perform farm labor in this country. All seven men reported they drank heavily at some time in their life. Many but by no means all agricultural workers drink. The oldest person (male) drank heavily. Similar to many women who perform farm labor, the woman neither drank nor used drugs. At some point in their life, all seven men had used marijuana, and four of the seven had used crack-cocaine in the past. These three (crack, marijuana and alcohol) are the most common drugs used by farm workers $[27,28]$. One man tried crack but stopped when it made him ill; two never used crack. Similar to a trend common in Latin America, four of six men used pills in their teens, and three of five men from Central America used inhalants, often before or simultaneous to initiating their use of marijuana and alcohol. Nonetheless, the atypical nature of involvement with drugs, but not alcohol, places these seven men at the extreme in terms of their experience with difficult times and potential risk for apprehension and injury. Despite the nonuse of drugs or alcohol, the experience of the lone woman in this random sample reflects the difficulties that are encountered by someone who depends on agricultural labor for economic livelihood.

\section{TRANS-MIGRANT NARRATIVES}

The eight trans-migrants are described in order of chronological age. I chose this order for presentation, since it avoids bias in my discussion of the manifestation of the humor response in the course of each person narrating aspects of individual experience. Rather than select names of my own choosing, I generated a set of fictive names which I randomly selected using a table of random numbers. I first selected letters under which the sample surnames were alphabetized, before selecting surnames from a compendium of 12,567 Hispanic surnames elicited from the 1980 Census of the U.S. population [29]. I used random numbers to select first names from a bibliographic list in the same volume and randomly mixed the first names with the randomly-selected surnames. My rationale was to eliminate subjective interpretations of personal identity either by myself or from the reader's experience with persons who "cross national borders."

> Woman Age 25: Born in central province, Mexico; parents deceased. Assisted by coyote ("border crossing facilitator"), Tomasina Navia and 13 men took eight days to cross the border to enter the United States. She was the only woman. Twelve men and the coyote were caught by immigration authorities. She and one man escaped and secured a ride with a truck driver, who took them to a "safe trailer." She subsequently lived and worked in one northern and two southern states. Her first husband injected drugs; using the bathroom, his use left a "funny odor" that she often noticed. When he began to miss work and money ran low, he tried to convince her to "prostitute herself" (venderse) to acquire drugs for him. She fled, leaving her two sons with him. She does not know where they currently live and she never regained custody of her children. She remarried. She recently learned that her uncle is a coyote, which she did not know at the time that she crossed the border. She has neither returned to Mexico and has yet to visit a grandmother who lives in California. She and her new husband have one pre-school child, and they currently live near his extended family.

Those places in Tomasina's interview where she inserted a chuckle or laugh consistently represent recognition of where she currently is in comparison to where she once was as a woman in Mexico. More than once, she chuckled while describing her dislike of farm work ("stooping over" in particular) and strong preference for work at the poultry plant. She recognized that in the United States, she had choices for work, even as a woman, despite restrictions on her because of her minimal skills in English. Like her departure from Mexico by herself, her decision to work in processing poultry contrasts with female neighbors who prefer work in the fields to the poultry plant (three friends were interviewed formally by the ethnographer). A willingness to withstand hardship (aguantarse) to seek a better life, first demonstrated in border crossing and underscored by her choice to travel with the men-only group, is repeated in a willingness to take the night shift at the plant. Curious about her adjustment, I asked her, "How do you do your day at night?" Chuckling, she replied, "I don't know why, right? Already I'm accustomed to the night work."

Since Tomasina has little contact with surviving kin in Mexico, she laughed at my question about contact with those who were in the group of 14 persons who intended to cross the border. As a testimony to her participation in the community of workers and families in the local area where I recruited her for this study, she knew that among the dozen men who crossed the border with her years earlier, two currently were working in a nearby poultry plant. She maintains her involvement with neighbors as well as her extended family. Certain parts of her story are known to those with whom she shares work time and living space. Her abrupt departure from her prior husband is the one place in her narrative where she had difficulty speaking the unspeakable. It is this part of her life, where she lived with uncertainty, that is rarely if ever shared with friends or family.

> Man Age 30: Raised in El Salvador, two brothers spent time in the military; married, one son, one daughter. Francisco De Rivera came to the states at age 19, lived in a southern city with his uncles and worked with a crew that painted condominium apartments. He left over problems with barrio gangs, about the same time that he and his friends were caught by police removing parts from a car inside a gated community. He went to the East Coast for three months, before moving to another southern state. Although he has gone to other states, he prefers staying in one town and working with one entrepreneurial-contractor of agricultural workers, a practice that is not atypical among agricultural workers [19]. The last time he communicated with his family was two years ago, when he called his mother.

Similar to men and women in the corpus of interviews I completed, I had known Francisco prior to our formal interview. As we started, I reminded him that we met through the health study that provided HIV testing to men and women in the farm town. "You took my blood and boy!" He exhaled and chuckled. Like others in that study, he was not fond of needles, and experienced a little anxiety over the two weeks 
while he awaited test results. The day that I taped his words as we sat in my car, he recounted the sad times of his life, particularly the hard times in agriculture, as well as separation from his family in El Salvador. While recounting experiences, he chuckled at the severe experiences. One incident that he expanded into a story occurred one night in the town where he formerly resided, when he was arrested with several companions as they stripped parts from a car in the gated community. He began the story by blaming nephews for "snitching" (pusieron el dedo) on him, framing the story with a comment that he and four companions were inside a parking garage, before adding that they were drunk. When I pointed out that drinking is not illegal, he explained that they had entered the gated community using the gate card from a buddy who was working for the condominium apartment complex. He laughed at their choice of cars to dismantle; they chose the one that had the most chromium. As they were drinking and dismantling its parts, the police descended on them. According to data we collected during the health study and material from related interviews I completed for this study, Francisco had never spent time in jail nor has he had further trouble with the police, after he left Texas. This incident obviously left him with a remembrance of the need to take caution.

Throughout the course of the interview, Francisco occasionally countered my comments and questions with statements that gave him and me moments of comic relief. As he described eight days of walking through desert to cross the border, I asked for clarification if he and three companions came with a coyote. He replied matter-of-factly that they "walked and walked," eating a loaf of bread they had bought in a store, before they left. When I asked what they did for water, he casually remarked that, "Water was found any place one wanted to drink," chuckling at the incongruity of assuming that one could drink water from the kind of places where it might be found in the desert. Although he described circumstances of his departure (his mother told him to leave his home country rather than join his brothers in the military) and underscored the loss that he carried for those he left behind (two now-married sisters and a grandmother who was alive when he left), the points at which he laughed were choices that he made in El Salvador (he took mushrooms and smoked marijuana) and a situation that he could never change (his wife took another man, sometime after he left). Someone "beat me to the task" (me ganó el manda'o) was the way that he described loss of his wife to another man. Francisco was reflecting on events in his life that turned out differently than his expectations. His use of the humor response marked the pain he felt at the loss of proximity to his family. Choices he made in El Salvador to use drugs were continued in this country with occasional experimentation with crack-cocaine and frequent consumption of alcohol. Owing to the choices and lifestyle that he left behind, the humor response marked transitions in his life whose outcomes continue to affect him today.

> Man Age 31: Born in capital city of a central province, Mexico; parents separated, raised by his grandparents. When his grandparents died, Jorge Mecartea left for the border at age 12 , where he worked as a bricklayer. When companions from his barrio told him that his mother was sad (triste), he returned home at age 18, where he married and lived for several years. He later came to the states with a buddy (village- based friendship), where he worked before returning to his home province. After a fight with his wife shortly thereafter (they have three children), he returned to the same state where he had previously worked.

Jorge had two interviews randomly selected. He chuckled at several points in the first interview in relation to what he had learned over the few years that he had spent in this country. These situations mostly described variation in rates of pay in two states of the rural South, and choices he had made to become heavily involved with crack-cocaine when he might better have chosen to spend his money to buy beer. He initiated this portion of his narrative as he mentioned, chuckling, that one learned among friends to roll marijuana cigarettes in the context of the barrio in Mexico ("he who doesn't know, doesn't smoke when it's offered") had turned against him in the States. Later in another town, he followed the lead of others and became addicted to crack.

More serious in the second interview, he elaborated details on his family, separation of his parents when he was young, and his drug experience (glue, paint, marijuana, alcohol in Mexico; crack-cocaine in the U.S.) and his older brother's success as a lawyer. When he talked of men who injected, he clarified (to my question) that he was referring to men who injected heroin or cocaine. When I commented that their experience differed from his, he asked me, "In Mexico?" To me this was incongruent with my assumption that he encountered injectors ("shooters") in the United States, not in Mexico. I was surprised. By asking me if I meant Mexico, he was anchoring himself to his drug experience with inhalants and marijuana in Mexico, and extending that to his recent experience with crack in this country. He indicated that drug use in the United States was intense and more individualized than he had witnessed or experienced in Mexico, where it was a social event among friends. Unlike Francisco, the humor response in Jorge's narrative (first interview) marked circumstances with very different consequences from behavior that was appropriate to his barrio in Mexico. He became nostalgic as well as saddened over his new circumstances during our second interview, recognizing that he would need to repair what had remained of the relationship with his wife, before he would have a secure place, if he chose to return to Mexico.

> Man Age 34: Raised in border province, Mexico; first came to U.S. alone at age 22, spent three months in a border state, before returning to Mexico. Alfonso Yriarte returned four times: once with his brother, sister's husband and his brother to the West Coast for a few days; once to a desert state for ten weeks; and later to the Midwest, where he and his brother were separated (his brother went by mistake to Chicago); and a second time to the Midwest. Alfonso worked on farms in the Midwest and three states on the East Coast, and for a brief time, he worked for a wrecking company in a port city on the Gulf of Mexico. The foreman from the farm where he worked in the Midwest brought him to the rural South three years prior to our interview.

Alfonso spoke with me in English that he learned while spending time in jail in the United States. No newcomer to the legal system, he previously spent time in prison in Mexico. He chuckled numerous times in the course of our talk, particularly over situations that challenged him with moderate inconvenience: catching the wrong train in a border state; 
getting caught by immigration officials in a "sweep" of a labor corner in a western state; finding himself arrested two days after he signed a pawn slip for a stolen video recorder (VCR) in the capital city of an eastern state. He learned quickly from serious events. "Mouthing back" to Englishonly inmates in the county jail, for example, he was beaten and in another incident he had his ankle broken in an argument over Latino inmates' right to watch a Spanish channel. When he later told me that he disliked fighting, I asked him how he avoided fights. "Carefully," he told me, as he giggled. At that moment, he could take the liberty of a chuckle, having already established earlier in the interview how often he placed himself into situations with potentially serious circumstances.

Alfonso recognized that social change alters a situation. He recounted how local men beat Latinos on the East Coast when they attempted to share the warmth of fires that the men built in barrels near the labor corner, but chuckled how the situation later changed in two years as more Latinos arrived and altered the balance of power in the street. He noted that in recent months, before he left, that men of several ethnic origins were able to share the warmth of barrel fires. For situations that changed his behavior, he marked these with humor. He first tried crack in the border state, when a man offered his buddy and him a place to stay at his house, as they were preparing to sleep on pieces of cardboard alongside a fence. Instead of food, the man gave them each a "hit" of crack-cocaine. He chuckled in re-telling how they accepted the crack and asked no questions. Despite prior experience with drugs in Mexico (alcohol, peyote, pills, marijuana, and solvents), time spent in settings in the western states where drugs were used and one more instance of an offer of free crack, he found that the price of crack was too much. Alfonso didn't use it again until he came to the East Coast a few years later, when he began heavy crack use.

Alfonso touched me with his knack of incongruent analogy. While comparing the prison system in Mexico and the United States, he described how he went into hiding when authorities were searching for him and companions whom he accompanied to steal a tourist couple's car in a northern state in Mexico, at the border. Having already served time in a Mexican prison, he used an analogy to explain why he fled.

"The way they work down in Mexico is, they don't, well (brief pause), when they take you into the interrogation room, they don't do interviews like you are doing... They use many, many "instruments" (wry comment accompanied by a straight face).

He later came back to his hometown, when a friend in the police force said it was safe. He told authorities during a deposition that the recovered goods were never returned to the couple, and he was left alone by the authorities. He had learned how the system worked. What he learned, he used to protect himself by confronting the situation as it often had confronted him, unexpectedly.

> Man Age 34: Born in the northeastern United States, raised in the Caribbean; oldest of three (two younger sisters), lived with family on family potato farm. Jean-Paul dropped out of school in the eleventh grade to devote time to a lawn business that he started. He later worked in a local hospital. He again lived in the northeastern United States through Job
Corps (his birth in the U.S. qualified him), and he visited the northwestern United States a year later. Close to his mother who was concerned over his use of marijuana and cocaine, he was encouraged by her to come to the United States for treatment. She gave him a check and the address of a treatment program in the southern United States. There he lived for ten years, but he spent no more than two days in the treatment program recommended by his mother. Although he reduced marijuana use, he became fond of crack-cocaine. On a whim, he accepted an offer to work in the tobacco harvest of another state, when a labor recruiter came to the missionshelter where he was staying. The man's dressy clothes and talk by farm-experienced men in the van on the trip to the tobacco farm "sweetened the dream." He worked in the tobacco harvest a few weeks, before I met him in a treatment program (not the one earlier recommended by his mother), which he found a few weeks after he arrived at the eastern labor camp that first summer.

Jean-Paul enjoyed the opportunity to talk with me by interweaving insights that he gained during his time in this country on life as it was for him in the Caribbean, compared to life as it became for him in the United States. He was adept at noting incongruities in current or recent situations with the sense of identity that he developed as a Caribbean male. Recurring themes in his narrative were the smallness of his experience in the Caribbean compared to his ten years in the United States and the conversion of loss into gain. At times, the family farm where he was raised in the Caribbean became a "small potato farm" when talking about the large tobacco farm. To my question on the width of the Caribbean island where he was raised, he chuckled and told me, "Minutes." Disillusioned at the tobacco camp where he was taken (labor contractor supplied drugs offered to workers), he used the heart problem he developed with cocaine use when he first arrived in the states to convince the foreman at the farm that he required treatment.

Through the process of treatment and his own reflection, he noted an incongruity in his adolescent self-image and lifestyle. He lived in a bungalow behind his mother's house. He lacked true self-independence, since his mother prepared meals and his two sisters washed his clothes. He recognized how his dreams for a different life as a teen diverged from his lifestyle: "I would dress like Tubbs [when he was younger, the American television series, "Miami Vice," was broadcast to areas of the Caribbean] and sit in front of the TV, thinking of going to Miami...." In the evening, he would dress like the then-popular vice-detective who was adept at arresting drug dealers, but go out with his friends to smoke marijuana and snort cocaine. These juxtapositions in behavior continued in the states. His early experimentation placed him at risk. Since he feared needles, he never tried heroin. Instead, at a party with heroin users, he once injected himself with wine: "That scared me because I fell to the ground; my heart was beating fast... I filled the whole thing with wine... I'd stand up and fall down." He chuckled as he told me of the imbalanced sensation that he had felt. Rather than re-live what must have been distressful, he emphasized the humbled dimension of that experience. The opportunity to enter treatment from the labor camp provided Jean-Paul with a respite, giving him time to reflect and to re-structure past memories of his identity in the Caribbean as well as in the United States. 
> Man Age 36: Raised in coastal province, Mexico; moved to Mexico City at 16, worked for 11 years as a tailor. Two years after he moved, Fernando Torres-Martínez met a woman from a town in the same province. They married when he was 18; together they had five children. When the sixth died, they returned to their respective home towns to pay respect for the child. Although his mother (widowed when he was young) treated his wife well (e.g., shared her money), his wife's mother was rough on him. She convinced her daughter to stay when it came time to return to Mexico City. After an argument with his wife over the delay, he returned to the capital. Within 15 days, he painted the apartment and sold or gave away their belongings. He returned to his hometown to tell his mother what had taken place, before he left Mexico for the United States. He went to a town on the West Coast, where men from his province often went to work. He had never worked in agriculture but took harvesting work (avocado and citrus) for a season, before he moved to the East Coast where he worked four months in a factory located in a northeastern state and six months in a poultry plant in a small city along the East Coast. He then moved to the capital near the small city of that state, where he lived for seven months.

Fernando was the only male among the eight sampled men who had never tried crack. He recognized he had a drinking problem when he lost his supermarket job of unloading trucks. As he explained it, the foreman provided workers with alcohol on the job. Fernando drank all that he was offered, plus extra drinks that the other men did not want. From a good job in Mexico where he worked in a tailor shop that he operated below the apartment where he lived, Fernando found himself in the United States taking odd jobs through a "labor corner" in the rural South.

Fernando revealed two humorous situations in his narrative. He noted the lighter side in his wife's attachment to her mother, despite the fact that neither he nor his wife ever visited their respective home towns during nine years of marriage. He spent little time with her while at his mother's-inlaw house. He laughed over this lack of time: "She left me neither sun nor shade" (ni al sol ni a la sombra). He chuckled over the first time he drank alcohol. He went with several companions to a bar, where they invited him to drink a few bolas ("tumblers"). He chuckled at the incongruity of what he thought would be small copas ("cups") not the larger liter-sized bolas ("tumblers") they were served. He became drunk. When he left to walk home, he was robbed of his wallet, wristwatch and clothes; the most painful loss, as he described it, was his brand-name tennis shoes. Despite the humor that he inserted into his account of that loss, after the first time that he ever drank, he did not laugh while he recounted his current experience of securing work from the "labor corner" to which he would walk 70 minutes each way from where he was living. The seriousness of this situation was underscored by his silence on the fact that the area where he lived, the rent for housing was inexpensive and the area generally experienced higher crime rates than other areas of the town.

> Man Age 36: Born in capital city of central province, youngest of six children; family currently in Mexico. Jorge Ureste first came to the states with his oldest brother where they worked in a border state. When the brother returned to
Mexico owing to an injury from a kick from a cow on the farm, Jorge went to live with his mother's brother in a large city, and later lived in four other cities where he had no family, in the Midwestern United States where he lived with an aunt and worked in a machine shop, and small towns in the rural South he worked in citrus, as well as brief periods in small towns in three other southern states. He worked within and outside agriculture in more than one state, and held several unskilled positions over the years: clerk in a hardware store, golf course groundskeeper, and delivery person for a Mexican-owned bakery, among others. He worked as a fruit vendor (plataformista) in his home province, before coming to the states, and each time he returned home (four times), he worked for a brief period as a fruit vendor, before returning to the states. Jorge was active in a local political party that "took-over" lands at the edge of town owned by landed farmers. Interestingly, he himself never petitioned to secure land for himself or his family.

Jorge judiciously spread humor throughout his interview. He created a narrative that was purposively incongruent at times to emphasize the ambiguity of situations in which he became entangled and at those points in his life when he gained a sense of identity as a Mexican male with equal time in the United States and Mexico. He found humor in the story that he told to reply to my first question during the second of four formal interviews (second was randomly sampled). To my question, he described the Midwest as the most difficult place he had lived which he illustrated by offering me the story of the night that he was summoned from a bar to defend a friend who had been attacked by gang members at another bar. As an indication of his adherence to the assumption that a Mexican male defends his buddies, he used the term cantina for "bar" at this juncture in the interview (otherwise the Anglicized barra, which is the common term among farm workers, was used to describe his other drinking episodes). When they arrived by car, one gang member shot at them, whereupon the bar security guards locked the doors. He chuckled at being forced to flee the scene, and he again chuckled at having to run from a pistol-toting gang member who was chasing him. He was wearing loose sandals at the time, which he lost. More than this, he cut his ankle to the bone during flight. He was gracious and voluntarily showed me the ankle scar. At this point he neither grimaced nor laughed. I was left to complete the story with an affective response of my own upon seeing the thick scar that spread across his ankle.

Having obliged my first question, Jorge began his narrative. He was a conversationalist. I mostly asked questions to clarify points that I missed. He amplified the story of leaving the farm where his brother was injured. To this time, he had little knowledge of the United States. He was looking forward to seeing gabachos (White Anglos), who, he had been told by friends, inhabited this country. The day for the trip with the coyote was rainy. The first point at which he laughs is when he observed Black people as they entered a near-theborder city. He was disappointed, since he had believed that the United States was inhabited only by white people. He chuckled,

"I looked and looked, and all I saw was Black, and more Black, 'My friends lied to me, right?' I told myself. How could this be? Black people. They never told me (chuckle) in 
Mexico that Anglos liked Black folks that much... Then we came to the safe house, where the door opened, (chuckle) [we went inside], they brought us chicken and beer."

Jorge brings himself to reflect on a reality that goes beyond that of his experience in the United States. If he stayed with compatriots that shared aspects of his background, he was safe. At the same time, the places where they worked and lived, and what he was offered in the course of those experiences, began to entangle him in what became a longterm addiction to alcohol.

Jorge used the momentum of this first story to draw closure to the interview. He described his experience when he went to the East Coast, a place with many beaches he had been told. "What beaches! All I saw was oranges in all directions." At this point, humor in the situation strikes me, as he is disguising, mockingly, that he spent all his time working in the orchards. Jorge continues by connecting the threads first mentioned in his introduction at the point that he draws closure to the second interview.

"What I saw was tizones [literally, "carbon"], Black folks (morenos). I told myself, "They robbed me of Anglos (los güeros) and they put Black folks in their place... Just like they robbed me of the beaches (las playas) and replaced them with oranges (naranjas)..."

There is a subtle truth to Jorge's perceptive comments, since many low-income areas where men and women from Central America typically find housing and/or work is cooccupied by African Americans who themselves also earn low wages. His poignant comment positions the transmigrant's disenfranchisement in work and residence: he is "permitted" to work in this country but, owing to low pay, is required to live in low-income areas without the opportunity to engage in this country's pleasures or to participate in mainstream society.

> Man Age 44: Born in El Salvador; after high school graduation, he worked with a North American mining company in Nicaragua. Edgar Izabal left his mining job when civil war started in that country; he went to Mexico to work four years (mostly construction). Later he came to the East Coast (his brother arranged for a coyote to assist them in crossing the border), where he worked orange harvests for four years. He returned to El Salvador for six years and briefly worked in cotton harvests in Guatemala and in construction in Belize (he also spent time in jail for lacking documents). In 1990, he returned to the United States. By this time, Edgar had a wife and children, whom he left in El Salvador. He has harvested blueberries and cherries in the Midwest, tomatoes and peppers in two states along the East Coast, and tobacco in three other eastern states. He communicates sporadically by phone with his wife and family back in El Salvador.

By the time I did formal interviews with Edgar, I had observed him over several years develop self-assurance about himself and his ability to find work. He left crack, which he used extensively during the early years I knew him, and alternated between moderate use of marijuana (initiated with teens he met in a park in Nicaragua) and alcohol. He was known by and in turn knew many of the men and women who spent time in the streets, and he initiated conversations or put people in contact with others who needed jobs or favors. Our previous conversations had been informal and touched on issues of concern to transnational men in the United States such as the lack of English skills or family left behind in a home country. I was not surprised that both Edgar and I laughed throughout the two formal interviews. I chuckled, for example, when he subverted a question that I asked on differences in tree work versus field work (I mentioned that one uses a ladder in the first, but one stoops to ground in the second). "That's a problem?" he dead-panned. His reply was one that came close to undermining my position as interviewer, but it was done in a way that reinforced his willingness to perform either tree work or field work, or both, as well as challenge my manner of conceptualizing labor according to frequent description in the ethnographic literature (stoop labor is described as demanding and difficult). I switched from differences in work conditions to ask if there were differences in pay rates. He continued, again in dead-pan, with a reply that permitted him to characterize each as similar in very low wages for pay. Both through working in the citrus groves and in ground crops, he said, he was able to make sufficient money for meals, which implied that there was very little left after the food had been purchased.

The points in his narrative that he found most humorous were contexts related to personal growth and change in behavior. In the first interview, he responded to my last question where I gave interviewees an opportunity to talk about something that "we may have left out." He took the invitation to express ideas on gender relationships in today's world, indicating that a man's resources were more important to a woman than a man's looks or behavior or her affection for him. He code-switched to English to quote a friend who told him, "You no got money, you no get honey," paraphrase of the common refrain heard in street talk in the rural South: "No Money, No Honey" ("honey" is a street metaphor for romance and sex). He drew upon his experience of ten years in the United States and ten years in countries other than his own in Central America to make this implicit comparison. I should add the context of this interview was that it took place on a Sunday morning after a full weekend of "entertainment" for men who lived in the center of town, Edgar among them. It was not unlike other times that we spoke informally over the years that I knew him. Through each conversation he brought me closer to situations and issues that recently were experienced by himself or someone he knew, for example, his travel to a new job in a coastal city along the East Coast; someone who recently was robbed in town; or, on this day, his recollection of times past, most likely triggered by the events of the past weekend.

In the second formal interview, Edgar chuckled while recounting an incident that took place with a friend. $\mathrm{He}$ bluntly told the friend one evening not to offer him a smoke of crack-cocaine, that the Divine Creator never intended for people to smoke drugs. His friend got angry with him and walked away. Edgar later noticed that his comment had an effect, since he noted that this friend would tell those who came to invite him to smoke, to not ask again: "No-no-nono, go smoke it yourselves, don't offer it to me, forget it." Pleased with his bold approach, Edgar emphasized transition in his friend's behavior by repeating the man's words to illustrate and to verify that a change of behavior had taken place. 


\section{ANALYSIS}

These seven men and one woman have provided an atypical look at the experience of a transnational Diaspora within the United States. Their travel to locations in the United States is what sets them apart in "trans-migrant" experience from most men and women from other parts of the world who are transnational workers in the United States. All of the eight persons whom I introduced have lived in several locations. Each has lived in more than twenty sites prior to my contact with them in three primary locations in the southern United States. The difficulties they have faced in these locales and states find space in their stories and tales, "fragmented" at times owing to geographic displacement, the challenge of seeking a living in the low-income areas of rural towns and small cities, and socio-psychological pangs of separation by physical distance from families. Their narratives are less often "fragmented" owing to drug or alcohol use within the boundaries of their life experience [30]. They generally leave unspoken reflections on how their extreme, constant use of drugs and alcohol has "interrupted" their life trajectory, such as that which occurs with life-threatening or terminal illness [31]. Nonetheless it is this dimension that often is emphasized in the social science literature in a way that places essential priority on social identity according to whether one uses drugs or alcohol. Difficulties that they experienced are highlighted in some stories and tales more than others, and these accentuated sections of an overall life story become a testing ground for self-growth (especially for Alfonso and Jorge) as well as the backdrop that illuminates an ongoing renewal of identity through the experience of another place different from their origins (especially for Tomasina, Jean-Paul, and both Jorge and Edgar).

We are told that "soft talk" serves to alleviate the tension and residues of imagined slights of daily face-to-face encounters [9], as well as facilitate exit from entanglement by social conflict and momentary pain [31, 32]. Humor resonates with the experiences of the past that can readily be projected into the present $[13,33,34]$. That which is constructed in a context of social conflict and interpersonal tension [31,32] is permitted a space for revision, if a narrator makes that choice in the course of narrative disclosure. For the men and women whom I interviewed for this study, and specifically for the eight individuals whom I introduced in this essay, the past that is re-visited in narratives is often marked at key junctures with the "humor response." For some, the humor response co-occurs in recounting the painful aspects of past experience (e.g., Francisco, Alfonso, Jorge). For others, it marks negotiation and construction of a new identity across two or more worlds (e.g., Tomasina, Jean-Paul and Fernando). And for others, it signals recognition of paths taken and the behaviors subsequently enacted that lead the narrator into an entanglement with addiction (e.g., Jorge, Alfonso).

The "tang of emotion" [35] communicated through the humor response at times engaged the interviewer, as the speakers intended to create a co-narrative worth the time to listen [16]. I became challenged in my role as researcher and as "guide" in co-construction of the interview. As a challenge in the semi-artificial setting of an interview, the humor response had a potential for a "fusion of centers" in relation to speaker (interviewee) and ethnographer (interviewer). At times, I was reconstructing my sense of identity in the dual roles of interviewer (specific to the immediate setting) and ethnographer (general to the overall study), as each of the eight persons was permitted space to reconstruct a sense of personal identity, as each wished, or to explore issues which caught their attention when they surfaced through a narrative disclosure [36, 37].

This last example that I provide here falls outside the venues in which I spent most of my time in the streets of rural towns with agricultural workers. It was not part of a formal interview. Some of the formal interviews I conducted in a county jail and town stockade. In order to do this, I would call the captain who was in charge of the sheriff's office to arrange an afternoon or a morning when I could visit the jail for research interviews. The captain had assigned a lieutenant to assist him at the county jail, and a sergeant was assigned responsibility for the town stockade. The lieutenant had performed police work in a northern state, before moving to the South, and the sergeant (like the captain) had spent most if not all his adult life living in the southern United States.

One time near the middle of my study, I called the stockade and was told that the sergeant was at the county office, so I called the main headquarters, which was located in another locale. The lieutenant answered the phone; I recognized and greeted him, and I asked to speak with the sergeant. Generally my interactions over the phone were courteous but to the point, as I focused on the business of securing permission. This time was different. The lieutenant replied, "Yes, he's here. Just a minute, I'll ask him." With no effort to muffle his voice (the aside he made to the sergeant was audible to me), "It's the anthropologist; he wants to come over to your house and play." There was a brief silence as I heard the telephone passed to the sergeant. When he came on the line, I arranged a time to conduct interviews at the stockade for end of the week, before I thanked him and hung up. Then I burst out laughing (which was audible to no one but myself) since the term "house" used by the lieutenant was an adaptation of the euphemism, "Big House," that was used in the South to refer to prison as well as plantation owner's home. Hence, the unadorned term "house" refers to a jail. For a couple of days, I would laugh to myself when I thought of the statement, "He wants to come over to your house and play."

There was a subtle play of incongruity in the northerncareer police officer learning the culture of the rural South. It was an instance of learning that graciousness is the key to hospitality throughout the South: make other people comfortable. This, then, is the lesson that I had learned through the field interviews that I arranged across various settings with farm workers in several states. Each interviewee showed me how women and men in agriculture would come to terms with disappointment in their lives. Through shared and disclosed humor, they made themselves comfortable with a part of their personal identity, according to their current circumstances. Their embodied agency was plainly based on efforts to reconcile who they believed they were and the times that their actions belied this reality [12] owing to life challenges and sometimes temporary lapses in sound judgment. 


\section{CONCLUSION}

Humor serves multiple purposes in conversation, whether it is naturally-occurring talk or the created conversation that occurs within the context of an interview. When a person recounts an incident that was traumatic or difficult, replay of stress in recalling that event is minimized through the humor response [15] which typically also removes intent toward aggression [38]. The resulting confirmation of identity, at that moment, is removed from potentially stigmatizing outcomes [39]. Incidents are reframed and interactions between teller and listener are re-aligned with humor [40].

The making of identify is a lifetime process that incorporates both personal and social experience. For men and women who transmigrate, that is, immigrate to, and travel within, the United States to seek and secure agricultural employment, identity-making incorporates a wide field of action. Herdt and Stoller [41] remind us that subjective aspects of identity may remain elusive to ethnographic investigation, despite the weight that subjectivity carries in formation and transformation of social identity. For their work this applied to "sex talk," for my work this applies to "drug use." These hidden aspects of reframing one's identity through the contentious context of immigration are worthy of inclusion in the serious study of human relations. Seeking to understand how social identity is formed, modified and affirmed, it is necessary to make our work comprehensive in narrative analysis and discourse theory in order to bring us closer to the articulation of yet-to-be-learned truths of the human experience.

\section{ACKNOWLEDGMENTS}

Funding is graciously acknowledged for the two research projects on which field data for this article were secured: National Institute on Drug Abuse ("Drugs/AIDS Intervention among Migrant Workers," DA 07694), Norman L. Weatherby, Principal Investigator; Wenner-Gren Foundation for Anthropological Research ("Inscription in Drug Use among Farmworkers"), Keith V. Bletzer, Principal Investigator; as well as Faculty Grant-in-Aid from the College of Liberal Arts and Sciences, and a National Research Service Award through the Department of Anthropology, Arizona State University

\section{REFERENCES}

[1] Appadurai A. Global ethnoscapes: notes and queries for a transnational anthropology. In: Fox RG, Ed. Recapturing anthropology: working in the present, Santa Fe, New Mexico: United States University of New Mexico Press 1991; pp. 191-210.

[2] Limón JE. Representation, ethnicity, and the precursory ethnography: notes of a native anthropologist. In: Fox RG, Ed. Recapturing anthropology: working in the present, Santa Fe, New Mexico: United States School of American Research Press 1991; 115-35.

[3] Feldman A. On cultural anesthesia: from Desert Storm to Rodney King. Am Ethnol 1994; 21: 404-18.

[4] Limón JE. Carne, carnales and the carnivalesque: Bakhtinian batos, disorder and narrative discourse. Am Ethnol 1989; 16: 471-86.

[5] Jenkins R. Subversive laughter: the liberating power of comedy. New York City: Free Press 1994.

[6] Steinbeck J. The grapes of wrath. New York City: The Viking Press 1939.

[7] Friedland WH, Nelkin D. Migrant agricultural workers in America's northeast. New York City, Holt: Rinehart and Winston 1971.

[8] Du Bry T. Immigrants, settlers, and laborers: the socioeconomic transformation of a farming community. New York City, LFB: Scholarly Publishing LLC 2007.
[9] Benson P. El campo: faciality and structural violence in farm labor camps. Cult Anthropol 2008; 23(4): 589-629.

[10] Rivera T. Y No se lo tragó la tierra. Houston: Texas Piñata Books 1996.

[11] Bremmer J, Roodenburg H. A cultural history of humour: from antiquity to the present day. Oxford: England Polity Press 1997.

[12] Bruun H, Langlais R. On the embodied nature of action. Acta Sociol 2003; 46(1): 31-49.

[13] Eckardt AR. Sitting in the earth and laughing: a handbook of humor. New Brunswick, New Jersey: United States Transaction Publishers 1992.

[14] Koller MR. Humor and society: explorations in the sociology of humor. Inc, Houston, Texas: United States Cap and Gown Press 1988.

[15] Norrick NR. Issues in conversational joking. J Pragmat 2003; 35 : 1333-59.

[16] Norrick NR. Humor, tellability, and conarration in conversational storytelling. Text 2006; 24(1): 79-111.

[17] Berger AA. An anatomy of humor. Transaction Books. New Jersey: United States New Brunswick 1993.

[18] Schensul SL, Schensul JJ, LeCompte MD. "Ethnographic sampling.” In: Schensul SL, Schensul JJ, LeCompte MD, Eds. Essential ethnographic methods: observations, interviews and questionnaires. Ethnographer's toolkit, Walnut Creek, California: United States Altamira Press 1999; Vol. 2: pp. 231-69.

[19] Griffith D, Kissam E. Farmworkers in the United States. Philadelphia, Pennsylvania: United States Temple University Press 1995.

[20] Heppel ML, Amendola SL. Immigration reform and perishable crop agriculture. New York City: University Press of America 1992.

[21] Carroll D, Gafford S, Myers J, Baron S, Steege A. Findings from the National Agricultural Workers Survey. Farm Worker Research and Results Workshop, Tenth Annual West Migrant Stream Forum, Portland, Oregon, United States 2001.

[22] Davis MP. Mexican voices, American dreams: an oral history of Mexican immigrants to the United States. New York City, Henry: Holt and Company 1990.

[23] Hondagneu-Sotelo P. Gendered transitions: Mexican experiences of immigration. Berkeley, California: United States University of California Press 1994.

[24] Rothenburg D. With these hands: the hidden world of migrant farm workers today. New York City: Harcourt Brace and Company 1998.

[25] Conover T. Coyotes: A journey through the secret world of America's illegal aliens. New York City: Vintage Press 1987.

[26] Kandel WA. A profile of Mexican workers in United States agriculture. In: Durand J, Massey DS, Eds. Crossing the border: research from the Mexican Migration Project. Russell Sage Foundation: New York City 2004; pp. 235-64.

[27] Bletzer KV, Weatherby NL. Variation in drug use in southern farming communities: watermelon men in the rural South. Hum Org 2009; 68(2): 115-28.

[28] Bletzer KV. Open towns and manipulated indebtedness among agricultural workers in the New South. Am Ethnol 2004; 31(4): 530-51.

[29] Platt LD. Hispanic surnames and family history. United States Baltimore, Maryland: Genealogical Publishing Company 1996.

[30] Spicer P. Narrativity and the representation of experience in American Indian discourses about drinking. Cult Med Psychiatry 1998; 22: 136-69.

[31] Arno A. Disentangling indirectly: the joking debate in Fijian social control. In: Watson-Gegeo KA, White GM, Eds. Disentangling: conflict discourse in Pacific societies. Stanford, California, United States: Stanford University Press 1990; pp. 241-89.

[32] Sterk-Elifson C. Someone to count on: homeless, male drug users and their friendship relations. Urban Anthropol 1992; 21: 235-51.

[33] Desjarlais R. Struggling along: the possibilities for experience among the homeless mentally ill. Am Anthropol 1994; 96: 886901.

[34] Lanzara GF. Shifting stories: learning from a reflective experiment in a design process. In: Schön DA, Ed. The reflective turn: Case studies in and on education practice. New York City: Teachers College Press 1991; pp. 285-320.

[35] Urban G. A discourse-centered approach to culture: Native South American myths and rituals. Austin, Texas: United States University of Texas Press 1991. 
[36] Riessman CK. Narrative analysis. Newbury Park, California: United States Sage Publications 1993.

[37] Rosenwald GC, Ochberg RL, Eds. Storied lives: the cultural politics of self-understanding. New Haven, Connecticut: United States Yale University Press 1992.

[38] Matthews JK, Hancock JT, Dunham PJ. The roles of politeness and humor in the asymmetry of affect in verbal irony. Discourse Proc 2006; 41(1): 3-24.
[39] Cardeña I, Littlewood R. Humor as resistance: deviance and pathology from a ludic perspective. Anthropol Med 2006; 13(3): 285196.

[40] Buttny R. Therapeutic humor in retelling the clients' tellings. Text 2000; 21(3): 303-26.

[41] Herdt G, Stoller RJ. Intimate conversations: erotics and the study of culture. New York City: Columbia University Press 1990.

(C) Keith V. Bletzer; Licensee Bentham Open.

This is an open access article licensed under the terms of the Creative Commons Attribution Non-Commercial License (http://creativecommons.org/licenses/by-nc/3.0/) which permits unrestricted, non-commercial use, distribution and reproduction in any medium, provided the work is properly cited. 